УДК $007: 304: 001$

\title{
ДІАЛОГ І ДІАЛОГІЧНИЙ ТЕКСТ: ДЖЕРЕЛА, ЗАСАДИ, АДАПТАЦІЯ В МЕДІА
}

\author{
Ірина Табінська \\ Львівський національний університет імені Івана Франка, \\ вул. Генерала Чупринки, 49, 79044, Львів, Україна, \\ e-mail: maliukiruna23@gmail.com \\ https://orcid.org/0000-0001-8052-5162
}

У статті автор порівнює діалог та діалогічний текст, визначає межі спільного та відмінного між поняттями, подає власне визначення дефініції «діалогічний текст», говорить про первинність та вторинність понять. Також описано засади діалогу та діалогічного тексту, які формуються під впливом онтології, і передбачають безкінечну комунікацію. Опрацьовано сучасні теоретичні дослідження на цю тему, на основі яких і зроблені припущення, що діалогічний текст є компонентом діалогу, що поняття між собою не є тотожними. Прослідкувавши за адаптацією діалогу та діалогічного тексту у системі медіа (на основі теоретичних розвідок), автор робить висновок, що праць на цю тему є обмаль, а наукових розвідок про діалогічний текст у медіа немає зовсім.

Ключові слова: діалог, діалогічний текст, медіа, медіатекст.

Питання вивчення діалогу не втрачає своєї актуальності десятки років. Діалог є об’єктом дослідження з лінгвістики, літературознавства, філософії, педагогіки, культурології, психології. Говорять про нього, коли йдеться про міжособистісне спілкування, про внутрішні монологи, про потребу діалогу на різних рівнях: політичному, екуменічному, соціальному. Багатогранність діалогу дозволяє різним наукам адаптовувати його до певних теорій та у якійсь мірі привласнювати. Журналістикознавство не стало винятком. Вивчають діалог як форму, як жанр, але передовсім звертають увагу на діалог як основу для діалогічних текстів. Актуальність таких наукових розвідок не викликає сумніву, оскільки діалог є універсальною формою для спілкування, порозуміння, в основі діалогу закладена комунікація. Актуальність статті зумовлена потребою наукового осмислення діалогу та діалогічного тексту в друкованих медіатекстах, їхньої ролі для комунікації між автором та читачем. Метою цієї статті є визначення джерел та засад діалогу і діалогічного тексту. Для досягнення мети ми поставили такі завдання:

1. З’ясувати дефініцію понять «діалог», «діалогічний текст». Пояснити спільне та відмінне між термінами.

2. Описати засади діалогу та діалогічного тексту.

(c) Табінська I., 2019

Наукове керівництво і рекомендація до друку - доц. Дацишин Х. П. 
3. Опрацювати сучасні дослідження на цю тему.

4. Прослідкувати за адаптацією діалогу та діалогічного тексту у системі медіа (на основі теоретичних розвідок).

5. На основі опрацьованих джерел дати власне визначення поняттю «діалогічний текст», яке буде стосуватися медійних текстів.

Вважається, що основи діалогу і загалом філософія діалогу були закладені ще за часів Сократа. «Діалог» 3 грецької мови - це «полеміка», «бесіда», «дискусія». Завдяки діалогу виробляється вміння послідовно міркувати [12, 235]. I. Михайлин подає визначення, що «сократичний діалог - метод обговорення певного питання на засадах поваги співрозмовників один до одного і спільного пошуку істини... Для сучасної журналістики, яка дотримується моделі соиіальної відповідальності й головною метою якої є переведення конфліктів у план дискусії, надзвичайно важливо володіти методом сократівського діалогу, залучати сторони до спільного пошуку істини, иляхів розв'язання обговорюваних проблем» [9, 128-129].

Основи теорії діалогу були закладені у 20-30-х роках XX ст. в працях М. Бубеpa, М. Бахтіна, Л. Якубинського, Л. Щерби, С. Поліванова. До їхніх лінгвістичних концепцій, де важливу роль відіграє текст як складова комунікації, звернулися такі українські науковці: М. Зубрицька, А. Юриняк, О. Лапко, О. Сінченко, О. Харитоненко. Діалогічний текст вивчають також Л. Безугла, Л. Дускаєва.

Діалог частіше досліджують у художній літературі, наукові роботи, що стосуються 3МI, є поодинокими. Але в обох випадках маємо справу з формулами «Література $=$ автор + текст + читач» та «Журналістика $=$ автор + текст + читач», тому теоретична літературознавча база може частково підходити і для нашої розвідки. Але якщо до уваги брати дослідження з лінгвістики, де діалог - це діалогічний текст, який протиставляється монологічному текстові [3], тобто «діалог» і «діалогічний текст» - це тотожні поняття, то такі підходи до трактування термінів не є для нас фундаментальними.

Для нас очевидним і зрозумілим $є$ те, що діалог може існувати не лише в усній формі. Діалогічність у мові виражається симбіозом смислових позицій, діалог повинен мати декілька голосів, аби вийшла ефективна комунікація. Це є фундаментом для тексту і його першочерговою властивістю. Тексти, окрім двох векторів: адресування та отримання відповіді, можуть містити діалоги у монологічних матеріалах. «Останні представлені не тільки способами і засобами, запозиченими з усного діалогу, а й засобами, виробленими спецііально в письмовій мові для иього» [7, 9-10]. Ми погоджуємося $з$ думкою, що кожен монолог $є$ діалогічним, і таким чином не надаємо великого значення лінгвістичним дослідженням, які чітко розмежовують діалог $\mathrm{i}$ монолог, оскільки нам недоречне розрізнення цих понять за кількістю комунікантів.

Дослідниця Л. Дускаєва наголошує, що діалог найбільш явно експлікується в діалозі як формі мови, але також пронизує іншу мовну форму - монолог. Відповідно, діалогічність властива не тільки діалогічним текстам на вигляд (де фіксується розмова двох), але монологічним [7: 32]. Цитата М. Бахтіна також цьому підтвердження: «Яким би монологічним не було висловлювання (наприклад, науковий чи фiлософський твір), як би воно не було зосереджене на своєму предметі, воно не може не бути і відповіддю на те, що було вже сказано на цей предмет, навіть якщо б та відповідь не отримала виразного зовнімнього вираження...» [1, 314-315]. 
У засобах масової інформації комунікація, що й передбачає діалоги, будується з урахуванням орієнтації на групову аудиторію. У цілому автор попри масову спрямованість може вести безпосередньо діалог з кожним читачем. Діалогічність $€$ в різних типах текстів - власне у діалогах, міжтекстових та монологічних ззовні. За дослідницею I. Сметюк, яка висловила думку, що «монолог - це згорнутий діалог», можна стверджувати, що у кожному монолозі $є$ діалог, і межі їх різниці $є$ розмитими [10].

Згідно з визначенням М. Бахтіна, «діалог за своєю простотою та чіткістю класична форма мовленнєвого спілкування. Кожна репліка, якою б короткою та уривчастою вона не була, володіє специфічною завершеністю, виражає певну позицію мовия, на яку можна відповісти і зайняти певну позииію щздо неї» [1, 310]. Такі зв'язки, на думку вченого, існують між репліками діалогу: пов’язаність питання - відповіді, стверджування - заперечення, ствердження - згоди, наказу - виконання. «Така взаємопов'язаність можлива тільки між висловлюваннями різних мовленнєвих суб'єктів і передбачає другого (у стосунку до мовия) члена мовленнєвого спілкування...» $[1,310]$. Як зазначає Л. Дротянко, філософія діалогу у М.Бахтіна грунтується на розумінні тексту, яке у його концепції має діалогічний характер. За М. Бахтіном, будь-який філософський чи літературний текст можна вважати діалогічним. 3 його концепції також випливає, що діалог є завжди первинним стосовно тексту [6]. Про первинність діалогу стосовно діалогічного тексту також зазначає Л. Безугла, вона зауважує, що діалог є первинним стосовно діалогічного дискурсу, а ще дослідниця поділяє діалог на функціональний та формальний: «Діалог на функиіональному рівні постає як мовлення у широкому розумінні, яке є підгрунтям мови як суспільного явищуа. Діалог на формальному рівні становить діалогічний текст, який є результатом реалізаиії діалогічного дискурсу. Діалогічний дискурс утворюється мовленнєвою діяльністю людини, яка за своєю природою є когнітивно-комунікативною, та результатом иієї діяльності - діалогічним текстом» [3].

На основі вищезазначених праць можемо підсумувати, що для нас діалог - це не рівнозначне поняття діалогічному тексту, оскільки діалог включає у себе діалогічний текст. Тобто окремий діалог може складатися з кількох діалогічних текстів. Діалогічний текст є компонентом діалогу, відповідно він вторинний, а діалог - первинний.

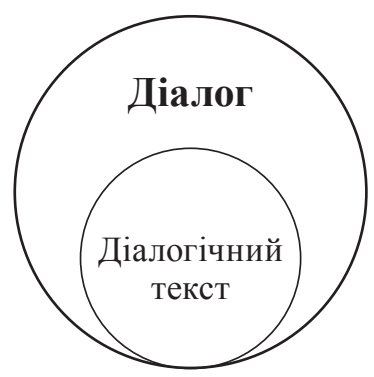

Словник-довідник для журналістів знайомить з такою інтерпретацією поняття: «Діалог (грец. dialogos - розмова, бесіда, букв. - слово двох) - інформаиійна взаємодія між учасниками комунікаиії, результатом якої є їх взаєморозуміння. Діалог передбачає почерговий обмін у процесі комунікації функиіональними ролями мовника i слухача» $[8,49]$. 
Діалогічністю не можна назвати звичайний обмін репліками. Діалог - це не розмова «ні про що», це змістовна бесіда, коли вектор розмови направлений у мислений центр, особу, яка «створює онтологію спілкування та розуміє сутнісні аспекти проблеми (об’єкта)» [5, 44]. За Є. Більченко, зведення діалогу до розмови - найпоширеніша помилка вживання даного слова. "Досвід спілкування та буття, який забезпечує діалог, - не просто ширший за розмову, але й взагалі може не бути розмовою, тобто вербальним спілкуванням двох осіб на засадах «толерантності» з метою досягнення компромісу» [4].

В. Гордієнко та Л. Копець тлумачать діалог як розмову про сутнісне. За їхніми переконаннями, діалог не може виникати просто як наслідок взаємного обміну репліками (повідомленнями). «Якщо немає утвореного смислу, який створений дбайливо іншими («володарями сутностей»), то розмова, бесіда, дискусія, суперечка не мають діалогічності, для иього вони мають потрапити в онтологію, щзо формується і розвивається на шляху до суті. Таким чином, діалог - це спілкування на тлі культури, історії, філософії, логіки. Тож иікаві для учасників активні розмови про несуттєві проблеми називати діалогом не варто» $[5,44]$.

Ми погоджуємося, що не всі думки, оформлені у діалог, є тим діалогом, який став об'єктом нашого дослідження. Все-таки діалог, зокрема у медіатекстах, повинен бути розмовою про вартісне і ціннісне, з відповідним тлом, уникаючи буденності та дріб'язкових проблем. Друкований медіатекст не передбачає забезпечення фатичної функції діалогу, «яка реалізується за посередництвом обміну ритуальними формами або навіть цілими діалогами, єдиною метою яких є підтримання комунікації» [13: 363]. Кожен діалог, що зав'язується у друкованих виданнях, є оригінальним, самодостатнім, а іноді і безкінечним. Діалог у друкованому медіатексті зазвичай не забезпечує комунікацію у звиклому вигляді. Йдеться про інший вимір діалогу, де через монологічний текст автор говорить з читачем. Засоби творення діалогічного тексту від автора забезпечують існування діалогу як фундаментального і глобального явища.

Комунікативні властивості діалогу зумовлюють специфіку вербалізації смислів у діалогічному тексті, тому є певні дослідження, які стосуються засобів творення діалогу. А якщо точніше, то діалогічного тексту, оскільки, як ми зазначали, діалог складається з діалогічних текстів. Л. Безугла виділяє такі мовні властивості діалогічного тексту (ознаки, засоби діалогізації, маркери діалогічності):

- морфологічні;

- синтаксичні [3].

До перших, на думку дослідниці, варто відносити: адресатні займенники, модальні слова, відсутність дієприкметників і дієприслівників, імперативний i умовний способи дієслова, модальні частки, модальні дієслова в суб'єктивно-епістемічному значенні, деграматикалізовані форми, перевага особових займенників. До других - повтори, звертання, паратаксис, вигуки, порушення порядку слів, приєднання, парцеляція, парентетичні звороти, односкладові, неповні й перервані висловлення, мовленнєві штампи, окличні звороти оцінної семантики, приказки, риторичні запитання, метакомунікативні вирази, ствердження й заперечення, еліпсис, комунікативні формули, звуконаслідування [3].

Л. Дускаєва роздумує над діалогічністю газетних текстів, тобто дає часткову інтерпретацію терміна «діалогічний текст»: «Діалогічність газетних текстів - фундаментальна їх властивість, не просто стилістичний прийом, але їх сутнісна риса, 
яка є текстовим виявленням сочіальної природи спілкування. Без ичієї властивості публіцистика втрачає свої важливі для ефективності спілкування якості» [7, 1718]. Діалог значною мірою представлений відповіддю. Відповідь медійних текстів викликана зовнішніми і внутрішніми екстралінгвістичними причинами. «3 одного боку, проникненням циих текстів у публіццистичний дискурс, проміжним положенням всякого тексту (всякий текст - реакція на перш висловлене і стимул для подальшого відповіді), з іншого боку, націленістю всякого тексту на передбачення можливих реакиій адресата» [7, 17].

Попри усю гуманітарність діалогів та зв'язків авторів з читачами отримуємо певні важливі формули для їхніх правильних відносин. Діалогічність в сучасних газетних текстах реалізується у взаємодії комунікантів, де, як наголошує науковець Л. Дускаєва, беруть участь, з одного боку, журналіст (Я), 3 іншого - або масова аудиторія (ВИ), або окремий читач (Ч), як alter ego автора (Я2), або «треті особи (ВІН1) i (BIH2).

Друга форма відображає адресованість читачеві ( «Я - ВИ») - пряму (питальну або спонукальну): непряму (у вигляді експресивної оцінки, вказівок на логіку викладу, акцентування важливих моментів змісту). Важливо зазначити, що адресність в цьому випадку теж має «відповідальний» характер, оскільки при їі використанні враховуються гіпотетичні особливості подальшого сприйняття тексту.

Третя форма часто зближуються з другою, виражає ідентифікацію позицій автора і читача («МИ з ВАМИ»)

Варто зазначити, що ці форми проявляються не тільки у діалогічних текстах, де розмова твориться за участю двох, але й у монологічних, де смислові позиції передаються однією особою - автором [7, 33].

Дослідники часто говорять про те, що діалоги переважно спостерігається у публіцистичних медіатекстах. 3 цього можемо припускати, що діалогічні тексти переважно трапляються у публіцистиці. Звідси гіпотеза, що у журналістиці є жанри діалогічні та недіалогічні. Тобто діалогічні жанри - ті, де $є$ засоби творення діалогу, діалогічний текст, а разом з тим і діалог, а недіалогічні - це тексти, в яких є речення, об'єднані спільним змістом, проте немає жодного натяку на діалог, відповідно нема діалогічних текстів, ані засобів творення діалогу.

На думку Л. Дротянко, діалог - все частіше поступається місцем колективній (публічній) комунікації, тобто масовій комунікації. За ii спостереженнями, засоби масової інформації - телебачення, радіо (особливо FM) - широко впроваджують інтерактивні програми, які передбачають діалог студії з телеглядачами і радіослухачами. «Електронні технічні пристрої дозволяють здійснювати таку інтеракцію, проте рівень культури мовлення співрозмовників у таких діалогах є надзвичайно низьким, як з боку організаторів діалогу, так і глядачів та слухачів» [6]. I хоч діалог у теле- та радіотексті не є об'єктом нашого дослідження, проте погоджуємося стосовного низького комунікативного рівня таких ЗМІ. Відповідно не можемо говорити про діалогічні тексти, зважаючи на те, що діалог не має онтологічного виміру, а виконує тільки фатичну функцію.

Можна стверджувати, що діалог встановлюється вже там, де є процес донесення інформації та процес ознайомлення з нею. «Між автором публіцистичного тексту і його читачем є діалоговий двосторонній контакт, який є саме двостороннім, навіть незважаючи на можливу пасивність рещчипієнта... Все ж будь-які дї, думки 
i адресанта (при написанні та передачі тексту), і адресата (у момент прочитання та осмислення) включені в діалог» $[11,95]$. О. Шалімова зауважує важливість діалогічної атмосфери, де автор і читач залучаються за допомогою публіцистичного тексту в єдиний діалогічний простір, і між ними встановлюється загальна діалогова атмосфера. На думку дослідниці, «ия атмосфера є вкрай важливою $і$ дієвою для адекватного ведення діалогу, але варто враховувати, що вона являє собою одночасно і крихке явище. Атмосфера може бути порушена, якщо адресат познайомиться з текстом поверхово, прочитає лише його частину» $[11,96]$.

Варто зазначити, що важливим чинником для продуктивного діалогу $є$ «рівноправність сторін, які беруть участь у комунікативному процесі» $[7,46]$, паритет. Саме за відсутності тиску на читача, при повазі до читача з боку автора, при запропонованій докладній розмові народжується бажання йти на контакт, розмовляти, обговорювати, реагувати, а, в кінцевому результаті, і діяти.

Дослідники зазначають, що діалог має сенс не лише тоді, коли учасники є добре підготовленими, а тоді, коли їхні знання є взаємозначущими: кожен знає щось, чого не знає інший. "Діалог спрямований на пошук своїх діалогічних партнерів («хто ще так думає?») та діалогічних опонентів («хто думає по-іншому?»). Діалогічне спілкування є реалізація емоційно та особистісно значущого сподівання, що я не один так думаю. Саме в різноголоссі (поліфонії діалогу) полягає його першочергове иіннісне та когнітивне значення» [5, 46-47].

За М. Бахтіним, соціальна сутність діалогу - головна риса цієї форми мовного спілкування, оскільки діалог пронизує всю промову. При цьому діалогічні відносини висловлювань являють собою зміну «смислових позицій». Смислова позиція це вираження життєвої позиції, погляду, певного розуміння факту, явища. У діалозі сходяться дві позиції, між якими і виникають діалогічні відносини [2].

На основі теоретичних вчень можемо сформулювати своє визначення для діалогічного тексту в медіа. На нашу думку, це офомлена у текст смислова позиція автоpa, яку він намагається подати читачеві, використовуючи засоби творення діалогів. Діалогічних текстів у самому тексті автора може бути кілька. Всі вони діалогують зі смисловими позиціями читача, відповідно забезпечують повноцінний діалог.

Вектори діалогу завжди спрямовані на іншого. Природа слова така, що воно завжди хоче бути почутим. На думку М. Бахтіна, слово завжди шукає потрібне розуміння і ніколи не залишається на одному рівні, а продовжує шукати все глибше розуміння. «Для слова (а отже, й для людини) немає нічого страшнішого, ніж безвідповідальність. Почутість як така - вже діалогічне відночення. Слово хоче бути почутим, мати відповідь $і$ знову відповідати на відповідь, і так аd infinituт. Воно вступає у діалог, який не має смислового завершення» [2, 322]. Якщо слідувати вченням М. Бахтіна, то випливає, що діалог ніколи не закінчується, відповідно діалогічні тексти в медіа завжди $є$ відкритими для читача. Сучасний діалог стає фундаментальною категорією, яка потрібна для інтерпретації усіх аспектів людського буття. «Діалог потрібно вести постійно і з усіма науками», оскільки діалог уже не літературний жанр, а буття свідомості $[12,235]$.

Вчень про діалог є чимало, оскільки його витоки сягають давніх часів, але обмаль досліджень, які безпосередньо стосуються діалогів у медіатекстах. Зазвичай науковці визначають діалог не тільки як розмову двох, не як звичайну комунікацію, але як онтологічну основу, як смисл буття, як безперервну комунікацію людства. 
Діалогічні тексти науковці-лінгвісти протиставляють монологічним текстам, проте, зважаючи на вчення М.Бахтіна, що кожен монолог є діалогом, варто розглядати їх як компонент діалогу. Також для вивчення діалогу і діалогічних текстів потрібне усвідомлення, що вони не тотожні поняття, що діалог є первинним, а діалогічний текст - вторинним. На основі теоретичних досліджень даємо власне визначення, що діалогічний текст у ЗМІ - це смислова позиція автора, яку він оформлює у текст і подає читачеві, використовуючи засоби творення діалогів. Зважаючи на те, що не всі медійні тексти містять діалог, можемо припускати, що існують діалогічні та недіалогічні жанри журналістики, тому наступні розвідки будуть стосуватися глибшого і детальнішого дослідження цієї гіпотези.

\section{REFERENCES}

1. Бахтін М. Висловлювання як одиниця мовленнєвого спілкування / Михайло Бахтін // Слово. Знак. Дискурс: Антологія світової літературно-критичної думки ХХ ст. / За ред. М. Зубрицької. Львів : Літопис, 1996. С. 308-317.

2. Бахтін М. Проблема тексту в лінгвістиці, філології та інших гуманітарних науках / Михайло Бахтін // Слово. Знак. Дискурс: Антологія світової літературно-критичної думки ХХ ст. / За ред.М.Зубрицької. Львів : Літопис, 1996. С. 318-323.

3. Безугла Л.Р. Діалог, діалогічний текст та діалогічний дискурс / Л.Р. Безугла // Харківський національний університет ім. В.Н. Каразіна Вісник Харківського національного університету ім.В.Н.Каразіна / Харківський національний університет ім. В.Н. Каразіна. Харків : Видавництво ХНУ ім. В.Н. Каразіна, 1964. N867 : Серія: Романо-германська філологія. Методика викладання іноземних мов. Вип. 60. 2009. C. 6-11.

4. Більченко Є. В. Діалог як логос феномена «Між» : по той бік принципу розмови / Є. В. Більченко // Поліфонія діалогу в постсучасній культурі : збірник наукових праць / упор. : С. М. Садовенко, Л. В. Терещенко-Кайдан. К. : НАКККіМ, 2013. С. 21-35.

5. Гордієнко В. І., Копець Л. В. Концептуальні засади дослідження діалогу / В. І. Гордієнко, Л. В. Копець // Наукові записки НаУКМА. Т. 136, Педагогічні, психологічні науки та соціальна робота / Національний університет «Києво-Могилянська академія». К. : ТОВ «Аграр Медіа Груп», 2012. С. 42-48

6. Дротянко Л. Г. Філософія діалогу в культурі інформаційної ери / Л. Г. Дротянко // Вісник Національного авіаційного університету. Серія : Філософія. Культурологія. 2015. № 1. С. 19-22. - Режим доступу: http://nbuv.gov.ua/UJRN/Vnau_f_2015_1_6

7. Дускаева Л. Р. Диалогическая природа газетных речевых жанров / Под ред. М.Н.Кожиной / Л.Р. Дускаева. СПб. : Изд. 2-е, доп., испр. СПбГУ: Филол. факультет, 2012. $274 \mathrm{c}$.

8. Журналістика : словник-довідник / авт.-уклад. І. Л. Михайлин. К. : Академвидав, 2013. 320 c.

9. Михайлин І. Л. Основи журналістики. Підручник. 5-те вид. перероб. та доп. / І. Л. Михайлин. К. : Центр учбової літератури, 2011. 496 с.

10. Сметюк И.Н. Диалогический текст: коммуникативно-динамический и лингводидактический аспекты: (на материале английского и русского языков) : Дис... канд. филол наук. / И.Н. Сметюк. Пермь, 1994. 20 с. 
11. Шалимова Е.В. Автор - публицистический текст - читатель / Е.В. Шалимова // Современная пресса : теория и опыт исследования / Под ред. Л.Л. Реснянской, Т.И. Фроловой. М. : ВК, 2007. С. 94-99

12. Шальман Т. М. Філософсько-комунікативні особливості дискурсу / Т. М. Шальман // Наукові записки Інституту журналістики : Т. 26 Січень - березень / Київський нац. ун-т ім. Т. Шевченка. К. : Видавництво Інституту журналістики, 2007. C. $235-239$

13. Якобсон Р. Лінгвістика і поетика / Роман Якобсон // Слово. Знак. Дискурс: Антологія світової літературно-критичної думки ХХ ст. / За ред. М.Зубрицької. Львів : Літопис, 1996. С. 357-377.

\title{
DIALOGUE AND DIALOGICAL TEXT: SOURCES, BASES, ADAPTATION IN MEDIA
}

\author{
Iryna Tabinska \\ Ivan Franko National University of Lviv, \\ Generala Chuprynky Str., 49, 79044, Lviv, Ukraine \\ e-mail: maliukiruna23@gmail.com \\ https://orcid.org/0000-0001-8052-5162
}

In this article the author compares the dialogue and the dialogical text, defines the boundaries of the common and distinct terms, provides the actual definition of the term «dialogical text», speaks of the primacy and secondaryness of concepts. Also described are the principles of dialogue and dialogical text, which are formed on an ontological basis, that is, infinite communication. The author worked out modern theoretical research on this topic, on the basis of which it was assumed that the dialogical text is a component of the dialogue. Following the adaptation of dialogue and dialogical text in the media system (based on theoretical research), the author concludes that there is little work on this topic, and there is no scientific research on dialogical text in the media at all.

Usually, scientists define the dialogue not only as a conversation of the two, not as an ordinary communication, but as an ontological basis, as the meaning of being, as the continuous communication of mankind. Dialogical texts by linguists are in contrast to monologues, but, given the doctrine of Bakhtin that every monologue is a dialogue, one should be seen as a component of dialogue. Also, for the study of dialogue and dialogical texts, we need to realize that they are not identical terms that the dialogue is primary, and the dialogical text is secondary. On the basis of theoretical studies, we give our own definition that the dialogical text in the media is a semantic position of the author, which he drafts in the text and gives to the reader, using means of creating dialogues. Given that not all media texts contain a dialogue, we can assume that there are dialogical and non- dialogical genres of journalism, so the following intelligence will apply to a deeper and more detailed study of this hypothesis.

Key words: dialogue, dialogue text, media, media text. 